\title{
Investigation of immunogenicity and protective efficiency of Bordetella bronchiseptica fimbriae in mice"
}

\author{
Özlem BÜYÜKTANIR ${ }^{\text {*** }}$, Mehmet AKAN², Erkan ÖZCENGIZZ ${ }^{\text {****}}$ \\ ${ }^{1}$ Refik Saydam Hygiene Center, Division of Vaccine and Sera, 06100 Ankara, Turkey, ${ }^{2}$ Ankara University, Faculty of Veterinary \\ Medicine, Department of Microbiology, Ankara/Turkey.
}

\begin{abstract}
Summary: Fimbrial proteins are important for adhesion and colonization of Bordetella bronchiseptica in the upper respiratory tract. In this study, determination of immunogenicity of the fimbrial proteins isolated from different strains of $B$. bronchiseptica and their protective efficacy against letal challenge was aimed. For this purpose, fimbrial proteins of seven standard strains and clinical isolates of B. bronchiseptica were partially purified by gel filtration chromatography and analysed by SDSPAGE. In microagglutination test, whole cell F415 was used as the antigen and the agglutination of sera from mice immunized with the purified fimbrial proteins was observed at titers of 1:128 for strains 219 and 4617 and the isolate CA; 1:256 for strain F415 and the isolate UK7; 1:512 for the isolate UK6 and 1:4096 for strain 3036. In addition, by ELISA against F415 fimbrial antigen, the antifimbriae antibody levels of the immune mouse sera were observed at serum dilutions of 1:6400 for UK7; 1:3200 for UK6, F415 and $3036 ; 1: 1600$ for CA; $1: 800$ for 219 and 1:400 for 4617 . The protective values of the fimbrial proteins against letal challenge with strain F415 in mice immunized with the fimbrial proteins ( $2 \times 25 \mu \mathrm{g} /$ dose) were; 100\% for F415 and 3036, 84\% for UK6 and 50\% for UK7, but no protection was observed with the other strains and isolates. In conclusion, fimbrial antigens were determined to have important protective efficacy and anti-fimbriae antibody levels were found correlated with that protective efficacy.
\end{abstract}

Key words: Bordetella bronchiseptica, fimbriae, immunogenicity, protective efficiency

\section{Bordetella bronchiseptica fimbriya proteinlerinin farelerde immunojenite ve koruyuculuk etkisinin araştırılması}

Özet: Bordetella bronchiseptica'nın üst solunum yollarında adhezyonu ve kolonize olmasında fimbriya proteinleri önemlidir. $\mathrm{Bu}$ çalışmada, B. bronchiseptica'nın farklı suşlarından elde edilen fimbriyal proteinlerin immunojenitesi ve canlı bakteri uygulamasına karşı koruyucu etkinliğinin belirlenmesi amaçlandı. B. bronchiseptica'ya ait toplam 7 standart suş ve klinik izolata ait fimbriya proteinleri, jel filtrasyon kromatografisi yoluyla kısmi olarak saflaştırıldı ve SDS-PAGE ile analiz edildi. Saflaştırılan fimbriya proteinleri ile bağışıklanan farelerin serumlarıyla F415 suşuna karşı yapılan mikroaglutinasyon testinde; 219 ve 4617 suşları ile CA izolatı için 1:128, F415 suşu ve UK7 izolatı için 1:256, UK6 izolatı için 1:512 ve 3036 suşu için 1:4096 titrede aglutinasyon gözlendi. Ayrıca, bağışık fare serumlarında, F415 fimbriya antijeni kullanılarak yapılan ELISA'da, UK7 için 1:6400; UK6, F415 ve 3036 için 1:3200; CA için 1:1600; 219 için 1:400 ve 4617 için 1:400 titrede antikor düzeyi belirlendi. Fimbriya proteinleri ile bağışıklanan farelerde $(2 \times 25 \mu \mathrm{g} / \mathrm{doz}), \mathrm{F} 415$ suşu ile yapılan canlı bakteri uygulamasında ise fimbriya proteinlerinin koruyucu değerleri; F415 ve 3036 suşları için \%100, UK6 için \%84 ve UK7 için \%50 olarak saptand1, diğer suş ve izolatlar için herhangi bir koruyucu değer gözlenmedi. Sonuç olarak, fimbriya antijenlerinin önemli koruyucu etkinliğe sahip olduğu ve anti-fimbriya antikor düzeyi ile bu koruyucu etkinlik arasında uyumlu bir ilişki olduğu belirlendi.

Anahtar sözcükler: Bordetella bronchiseptica, fimbriya, immünojenisite, koruyuculuk etkinliği

\section{Introduction}

Bordetella bronchiseptica is the causative agent of important respiratory diseases in domestic and wild mammalian animals including dogs, cats, pigs and experimental animals like rabbit, guinea pig and transmitted to humans, especially to immuncompromised patients $(1,2,7,9,15)$. B. bronchiseptica produces most of the virulence factors of B. pertussis, the etiologic agent of whooping cough, including adenylate cyclasehemolysin (AC-Hly) (10), filamentous hemagglutinin (FHA) (6), pertactin (15), Fim D (31), outer membrane porin proteins (24), dermonecrotic toxin (16) and fimbriae $(4,18,19,27)$. Among those proteins, fimbriae, FHA, and pertactin have roles in adherence and

\footnotetext{
* This study was prepared from a part of $\mathrm{PhD}$ thesis of the first author.

Present address of the authors:

** Ondokuz Mayıs University, Faculty of Veterinary Medicine, Department of Microbiology, Samsun/Turkey.

${ }^{* * * *}$ Vaccine Biologicals Research Inc. Hacettepe University Teknokent 1.Ar-Ge No: 4 Beytepe, Ankara/Turkey.
} 
colonization of the bacteria in the upper respiratory system $(4,6,15,31)$.

Fimbriae important in humoral immune response against $B$. bronchiseptica $(4,18,19)$ was also included in a vaccine for cats (13). Fimbriae was initially demonstrated to be constituted of three antigenically related 21, 22 and $24 \mathrm{kDa}$ fimbrial major subunit proteins by Lee et al. (1986) and shown to be expressed in variant quantities effecting the host species specificity of $B$. bronchiseptica strains (4). By different studies, fimbrial subunits of $B$. bronchiseptica were determined as Fim2, Fim3, FimX (expressed only at very low levels), FimA, FimN and FimD $(3,8,13,20,21,26,28)$. Although being the minor fimbrial subunit, $40 \mathrm{kDa}$ FimD, have important role in adhesion by affecting the expression of the major fimbrial subunits and being necessary in formation of the fimbrial structure $(8,31)$.

In this study, the immunogenicity and the protective immunity of the purified fimbrial proteins of $B$. bronchiseptica strains were comparatively evaluated.

\section{Materials and Methods}

Bacterial strains, antisera, media and culture conditions: B. bronchiseptica reference strains used in this study were F415 (Liverpool University, England), 219 and 3036 (Goetheborg University, Culture Collection, Sweden) and 4617 (ATCC). The clinical isolates; CA, UK6, UK7 were received from Ankara University, Faculty of Veterinary Medicine, Microbiology Department (Turkey). The strains and the isolates used in the study were confirmed by re-identification with biochemical tests as described by Holt et al. (1996) and lam agglutination with anti-F415 mouse sera.

Bordetella strains were grown on Bordet Gengou agar with $20 \%$ sheep blood and Modified-CohenWheeler agar prepared as prescribed previously, $B$. bronchiseptica for 24 hours, B. pertussis for 48 hours at $37^{\circ} \mathrm{C}(25,30)$. The colonies of all the strains were small and domed showing the virulent phase phenotype. Serum obtained from mice immunized with $B$. bronchiseptica F415 standard strain and B. pertussis fimbriae (Fim2,3) were used as the positive controls. Sera from mice which were injected PBS were used as the negative controls.

Whole cell extracts of the strains: $B$. bronchiseptica strains grown on modified CohenWheeler agar were harvested with PBS (pH: 7.4) and centrifuged at $5000 \mathrm{x} \mathrm{g}$ for $20 \mathrm{~min}$. The pellet was resuspended (30\%) in TSA buffer $(10 \mathrm{mM}$ Tris, $0.145 \mathrm{M}$ $\mathrm{NaCl}, 0.1 \% \mathrm{Na}$ azid, pH: 7.2) containing $5 \mathrm{mM} \mathrm{MgCl} 2$ and $2 \mathrm{M}$ urea. After incubation at $60^{\circ} \mathrm{C}$ for $45 \mathrm{~min}$ in water bath, the suspension was centrifuged for $30 \mathrm{~min}$ at $20000 \times \mathrm{g}$ at $+4^{\circ} \mathrm{C}$ (12) and the supernatant was obtained.

Purification of fimbriae: The supernatant was dialysed against TSA buffer and applied to gel filtration on $2.6 \times 60 \mathrm{~cm}$ column of Superdex 75 by using FPLC system (Biopilot, GE Pharmacia, Uppsala, Sweden) equilibrated with TSA buffer $(\mathrm{pH}: 8.0)$. The elution of the fractions was performed with TSA buffer. The protein peaks were combined separately and the fimbrial proteins were obtained from the second peak.

Immunizations: Groups of 4 weeks old mice (14-16 g) consisting of 10 animals were immunized intraperitoneally with $0.5 \mathrm{ml}$ of whole-cell proteins or the fimbrial proteins subcutaneously twice at 15 day intervals. For this purpose, whole cell proteins $\left(1.5 \times 10^{10}\right.$ bacteria $\mathrm{cfu} / \mathrm{ml}$ ) inactivated at $56^{\circ} \mathrm{C}$ for $30 \mathrm{~min}$ and the fimbrial proteins $(12.5 \mu \mathrm{g}$ and $25 \mu \mathrm{g} / \mathrm{ml})$ adsorbed to aluminum hydroxide gel (0.45 mg aluminum/dose, Sigma A8222) according to the manufacturer's instructions were used (30). Mice were bled 14 days after the second immunization and antibody levels were determined by microagglutination test and ELISA.

SDS-PAGE and western blot: The samples boiled for 2 min were separated by SDS-PAGE according to the method of Laemmli (1970) with the separating gel of $10 \%$ for the heat-urea extract and $12.5 \%$ for the purified proteins. The gels were either stained by silver stainning or electrophoretically transferred to nitrocellulose membrane $(0.2 \mu \mathrm{m}$, Sigma, N8017, St Louis, MO, USA) premoistened in electroblot buffer (30.3 g Tris, $144.2 \mathrm{~g}$ glycine/L) as described by Towbin et al. (1979). The transfer was performed at $1.5 \mathrm{~mA} / \mathrm{cm}^{2}$ for $1 \mathrm{~h}$. The nitrocellulose membrane blocked by $10 \%$ skimmed milk in PBS containing $0.05 \%$ Tween 20 overnight at $4^{\circ} \mathrm{C}$ was incubated with anti-F415 mouse serum diluted $1 / 100$ for $2 \mathrm{~h}$. Skimmed milk (5\%) in PBS containing $0.05 \%$ Tween 20 was used as the dilution buffer. The membrane was incubated with mouse $\operatorname{IgG}$ alkaline phosphatase conjugate (Sigma, A3438) diluted 1/30 000 for $1 \mathrm{~h}$ and the reaction was developed by incubation with alkaline phosphatase conjugate substrate kit (Bio-Rad, 170-6432, Hemel Hempstead, UK), consisting of nitroblue tetrazolium and 5-bromo-4 chloro-3 indolyl, until the bands were visible. The reaction was stopped by incubating the membrane in distilled water for $10 \mathrm{~min}$.

Dot blot immunoassay: The purified proteins were applied onto the nitrocellulose membranes $(0.2 \mu \mathrm{m}$, Sigma, N8017) and blocked with 5\% skimmed milk in TBS (20 mM Tris- $\mathrm{HCl}, 500 \mathrm{mM} \mathrm{NaCl}$; $\mathrm{pH}$ : 7.5) containing $0.05 \%$ Tween 20 overnight at $4^{\circ} \mathrm{C}$, also used as the dilution buffer. The membranes were incubated with anti-B. bronchiseptica F415 sera and anti-Fim2,3 of $B$. pertussis specific sera diluted $1 / 200$ for $2 \mathrm{~h}$ at room temperature (4). The enzymatic detection of the dots was performed as described in Western Blot analysis.

Microagglutination assay: Two fold serial dilutions of anti-fimbrial sera $(50 \mu \mathrm{l})$ were made in 96 well roundbottom microtiter plates starting at 1:4 and ending at 1:8192. An equal volume of bacterial suspension (optical density of 1.2 at $630 \mathrm{~nm}$ ) of B. bronchiseptica strains and 
isolates, as well as two strains of B. pertussis, Saadet and Tohama prepared in PBS by inactivation with formaldehyde $(0.25 \%)$ was added to each well. The plates were shaken gently and incubated at $37^{\circ} \mathrm{C}$ for $2 \mathrm{~h}$ and at $4^{\circ} \mathrm{C}$ for $18 \mathrm{~h}$. The reciprocal of the last dilution of agglutination was recorded as the serum titer $(4,23)$.

ELISA: Flat-bottomed ELISA plates were coated with $100 \mu \mathrm{l}$ of $4 \mu \mathrm{g} / \mathrm{ml}$ of $\mathrm{F} 415$ fimbriae protein prepared in $0.05 \mathrm{M}$ bicarbonate buffer ( $\mathrm{pH}$ 9.6) and kept overnight at room temperature. After blocking with $2 \%$ fetal calf serum (Sigma, F2442) in PBS containing 0.05\% Tween 20 for $1 \mathrm{~h}, 100 \mu \mathrm{l}$ of anti-B. bronchiseptica or antifimbriae sera two-fold serially diluted beginning with dilution of 1:100 to 1: 12800 (PBS, 0.05\% Tween 20, $2 \%$ fetal Calf Serum) were added to the microwells. After incubation for $2 \mathrm{~h}$, goat anti-mouse Ig G alkaline phosphatase conjugate (Sigma, A3438) diluted 1:30 000 was added and incubated for $2 \mathrm{~h}$ at room temperature. The reaction was developed with pNPP (paraNitrophenyl Phosphate disodium hexahydrate, Sigma, N9389) substrate tablets $(1 \mathrm{mg} / \mathrm{ml})$ (Sigma-Aldrich) dissolved in $10 \%$ ethanolamin (Sigma, 398136) containing $0.5 \mathrm{mM} \mathrm{MgCl}_{2}$ (pH 9.8). The plates were read at $405 \mathrm{~nm}$ in ELISA reader. The cut-off was determined as twice the mean adsorbance value of the negative sera.

Mouse protection test: Initially, the letal effect of $B$. bronchiseptica F415 strain to mice by intraperitoneal injection of live bacteria was determined by $\mathrm{LD}_{50}$ (letal dose 50) test meaning the minimum bacterial concentration which kills half the number of the mice in 7 days (29). Seven groups of mice each consisting of six mice immunized with two doses $(12.5$ and $25 \mu \mathrm{g})$ of fimbrial proteins were challenged intraperitoneally by the strain F415 with $4 \mathrm{LD}_{50}\left(2 \times 10^{9}\right.$ bacteria $)$ doses fifteen days after the second immunization and the number of survivors per group after challenge was recorded in 7 days $(18,22)$.

\section{Results}

Whole cell extracts of the strains: The major immuno-dominant antigens of $B$. bronchiseptica by SDSPAGE analysis of the urea-heat extracts of different strains were determined as FHA (220 kDa), AC-Hly (200 $\mathrm{kDa}), 40 \mathrm{kDa}$ protein, $35 \mathrm{kDa}$ protein and fimbrial subunits $(21 \mathrm{kDa}, 22 \mathrm{kDa})$. Western blot analysis of extracts of the strains with anti-whole cell F415 serum revealed the immuno-reactivity of these proteins (Fig 1).

Purification of fimbriae: Fimbrial proteins were partially purified from seven different strains of $B$. bronchiseptica by gel filtration chromatography using Superdex 75 column. Three protein peaks were obtained and the fractions of each peak were collected separately. The partially purified fimbriae observed by SDS-PAGE analysis at the second peak of the chromatogram was basically constituted of 2 fimbrial subunit proteins (21 and $22 \mathrm{kDa}$ ). Variations of fimbrial proteins belonging to different strains were observed as determined by SDSPAGE analysis (Fig 2). The fimbrial proteins were confirmed by dot-blot analysis using anti- $B$. bronchiseptica F415 sera and anti-Fim2,3 of B. pertussis specific sera.

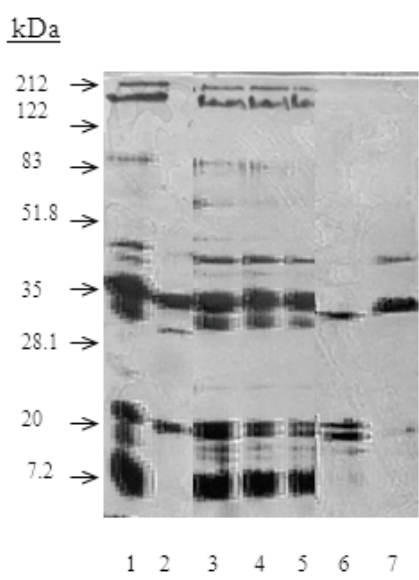

(A)

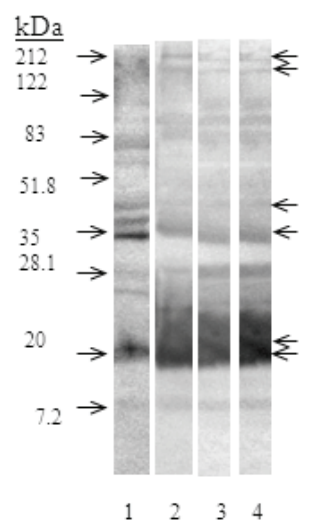

(B)
Figure 1. Evaluation of B. bronchiseptica extracts of different strains by SDS-PAGE (A) and Western Blot (B) analysis. Sera from mice immunized with strain F415 was used in Western Blot. (A) Lanes 1) F415, 2) 219, 3) UK6, 4) UK7, 5) 3036 6) 4617, 7) CA (B) Lanes 1) 3036, 2) UK6, 3) F415, 4) 4617. Molecular weight marker (BioRad) is shown by the arrows on the left. FHA, AC-Hly, $40 \mathrm{kDa}$ and $35 \mathrm{kDa}$ proteins, and fimbrial proteins $(21$ and $22 \mathrm{kDa}$ ) are shown by the arrows on the right.

Şekil 1. Farklı suşlara ait B. bronchiseptica ekstraktlarının SDS-PAGE (A) ve Western Blot (B) analizi ile değerlendirilmesi. Western Blot analizinde F415 suşu ile bağışıklanan fare serumu kullanıldı. (A) Şeritler 1) 3036, 2) UK6, 3) F415, 4) 4617. Molekül ağırlık belirteci (BioRad) solda oklarla gösterilmektedir. FHA, AC-Hly, $40 \mathrm{kDa}$ ve 35 $\mathrm{kDa}$ proteinler ve fimbriya proteinleri (21 ve $22 \mathrm{kDa}$ ) sağda oklarla gösterilmektedir.

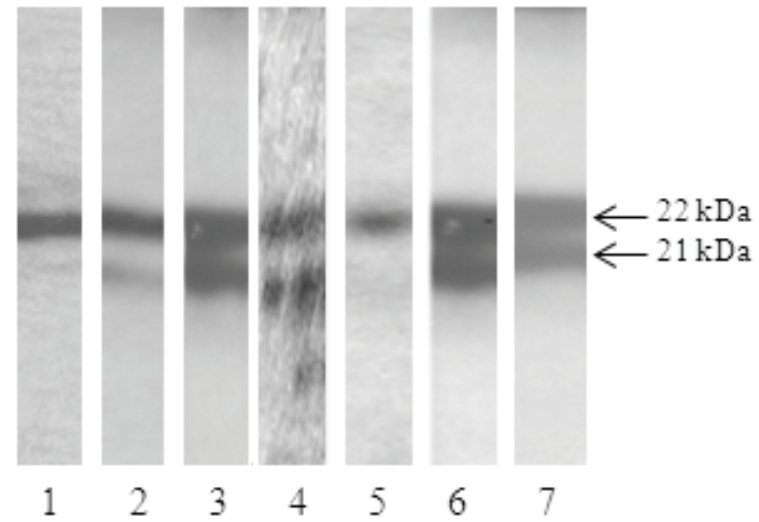

Fig 2. SDS-PAGE analysis of fimbrial proteins of $B$. bronchiseptica strains.

Lanes 1) 219, 2) 4617, 3) F415, 4) UK6, 5) CA, 6) UK7, 7) 3036

The fimbrial proteins and their molecular weights are shown by the arrows.

Şekil 2. B. bronchiseptica suşlarından saflaştırılan fimbriya proteinlerinin SDS-PAGE ile analizi.

Şeritler 1) 219, 2) 4617, 3) F415, 4) UK6, 5) CA, 6) UK7, 7) 3036

Fimbriya proteinleri ve molekül ağırlıkları oklarla gösterilmektedir. 
Table 1. Microagglutination titers of sera from mice immunized with two different doses $(12.5 \mu \mathrm{g}$ and $25 \mu \mathrm{g})$ of fimbrial proteins of B. bronchiseptica strains

Tablo 1. B. bronchiseptica suşları fimbriya proteinleri ile 2 farklı dozda (12.5 $\mu \mathrm{g}$ ve $25 \mu \mathrm{g})$ bağışılanan fare serumlarına ait mikroaglutinasyon titreleri

\begin{tabular}{|c|c|c|c|c|c|c|c|c|}
\hline & $\begin{array}{c}\text { Anti- } \\
\text { FimF415 titer }\end{array}$ & $\begin{array}{c}\text { Anti- } \\
\text { Fim219 } \\
\text { titer }\end{array}$ & $\begin{array}{c}\text { Anti- } \\
\text { Fim3036 } \\
\text { titer }\end{array}$ & $\begin{array}{c}\text { Anti- } \\
\text { FimUK6 } \\
\text { titer }\end{array}$ & $\begin{array}{c}\text { Anti- } \\
\text { FimUK7 } \\
\text { titer }\end{array}$ & $\begin{array}{c}\text { Anti- } \\
\text { Fim } C A \\
\text { titer }\end{array}$ & $\begin{array}{c}\text { Anti } \\
\text { Fim4617 } \\
\text { titer }\end{array}$ & $\begin{array}{l}\text { Negative } \\
\text { sera }\end{array}$ \\
\hline $\begin{array}{c}\text { Test } \\
\text { Antigens }\end{array}$ & $12.5 / 25 \mu g^{1}$ & $12.5 / 25 \mu g$ & $12.5 / 25 \mu g$ & $12.5 / 25 \mu g$ & $12.5 / 25 \mu g$ & $12.5 / 25 \mu g$ & $12.5 / 25 \mu g$ & PBS \\
\hline$C A$ & $128 / 128$ & $N / 32$ & $64 / 512$ & $64 / 128$ & $64 / N$ & $64 / 128$ & $128 / 128$ & $N^{2}$ \\
\hline 4617 & $N / N$ & $N / N$ & $N / 8$ & $N / 8$ & $N / 256$ & $N / 8$ & $256 / 4096$ & $N$ \\
\hline 219 & $4 / 64$ & $16 / 16$ & $4 / 32$ & $4 / 64$ & $4 / 64$ & $4 / 128$ & $4 / 512$ & $N$ \\
\hline F415 & $128 / 256$ & $N / 128$ & $128 / 4096$ & $128 / 512$ & $128 / 256$ & $64 / 128$ & $64 / 128$ & $N$ \\
\hline UK6 & $32 / 64$ & $N / 8$ & $128 / 1024$ & $64 / 512$ & $32 / 64$ & $8 / 16$ & $32 / 128$ & $N$ \\
\hline$U K 7$ & $32 / 32$ & $N / 16$ & $128 / 2048$ & $128 / 512$ & $32 / 128$ & $16 / 16$ & $64 / 128$ & $N$ \\
\hline 3036 & $64 / 64$ & $N / 128$ & $256 / 4096$ & $256 / 512$ & $64 / 128$ & $16 / 64$ & $64 / 256$ & $N$ \\
\hline Saadet $^{3}$ & ...... / 256 & $\ldots \ldots / N$ & $/ 256$ & .... / 128 & .... / 128 & $\ldots \ldots / 128$ & ..... / 128 & $N$ \\
\hline Tohama $^{3}$ & $\ldots \ldots . / N$ & $\ldots \ldots / 8$ & $/ 128$ & ..... / 32 & $\ldots . / N$ & $\ldots \ldots / N$ & $\ldots \ldots / N$ & $N$ \\
\hline : Fareler ik & $\begin{array}{l}\text { e immunized tw } \\
\text { ki defa bağış1kla }\end{array}$ & $\begin{array}{l}2: 1 \\
2: 1\end{array}$ & $\begin{array}{l}\text { Jegative sera ( } \\
\text { Jegatif serum ( }\end{array}$ & $\begin{array}{l}\text { m PBS injecte } \\
3 S \text { enjeksiyon }\end{array}$ & $\begin{array}{l}\text { mice) } \\
\text { yapilan fareler }\end{array}$ & & $\begin{array}{l}\text { ordetella pert } \\
\text { ordetella pert }\end{array}$ & $\begin{array}{l}\text { ssis strain } \\
\text { ssis suşu }\end{array}$ \\
\hline
\end{tabular}

Table 2. IgG antibody response in serially diluted sera of mice immunized with the purified fimbrial proteins of B. bronchiseptica strains in ELISA using F415 fimbriae antigen.

Tablo 2. Seri dilusyonları yapılmış $B$. bronchiseptica suşlarına ait saflaştırılmış fimbriya proteinleri ile bağışıklanan fare serumlarının ELISA'da (test antijeni F415 fimbriya) IgG antikor yanıtı.

\begin{tabular}{|c|c|c|c|c|c|c|c|c|}
\hline $\begin{array}{l}\text { Fimbrial proteins } \\
\text { used in immunization }\end{array}$ & $1: 100$ & $1: 200$ & $\begin{array}{c}\text { Antibody } \\
1: 400\end{array}$ & $\begin{array}{c}\text { Dilutions } \\
1: 800\end{array}$ & $1: 1600$ & $1: 3200$ & $1: 6400$ & $1: 12800$ \\
\hline UK6 & + & + & + & + & + & + & - & - \\
\hline UK7 & + & + & + & + & + & + & + & - \\
\hline F415 & + & + & + & + & + & + & - & - \\
\hline 3036 & + & + & + & + & + & + & & \\
\hline $\mathrm{CA}$ & + & + & + & + & + & - & - & - \\
\hline 219 & + & + & + & + & - & - & - & - \\
\hline 4617 & + & + & + & - & - & - & - & - \\
\hline
\end{tabular}

Microagglutination assay: The aglutinin response of mice immunized twice with two doses of the partially purified fimbriae obtained from 7 B. bronchiseptica strains were determined. Concerning the agglutinin titers of anti-F415 fimbriae sera against $B$. bronchiseptica strains, no or slight agglutinin titres were obtained with the Standard strains 219 and 4617. Higher titers were observed in the strains F415, 3036 as well as in the clinical isolates UK6 and UK7. In the same manner, no or low agglutinin titres were obtained with the immunizations using 219, 4617 and CA fimbriae. The agglutinin titers were relatively high with the immunizations using fimbriae of strains F415, 3036 and the isolates UK6 and UK7. Better results were obtained with the immunization dose of $25 \mu \mathrm{g}$ (Table 1). Furthermore, the agglutinin titers of anti-fimbriae sera of mice immunized with $B$. bronchiseptica strains and isolates when whole cell antigens of B. pertussis Saadet and Tohama strains were used ranged from no reaction to 256 and no reaction to 128 , respectively, however, the number of non-reactive sera with Tohama strain was very high. Cross-reactivity among the strains was also detected. The noteworthy data was the high microagglutination titer of anti-3036 fimbriae with the other strains except 4617 and 219 and the lowest titer of anti-219 fimbriae against the other strains.

ELISA: The IgG antibody response of mice immunized with fimbriae of B. bronchiseptica strains against F415 fimbrial antigen was determined by ELISA. High antibody levels were observed for anti-fimbriae of the isolates UK6, UK7 and the strains F415, 3036 with serum dilutions of 1:3200 - 1:6400. Antibody response at decreased dilutions of 1:1600, 1:800 and 1:400 was detected for CA, 219 and 4617 respectively (Table 2). 
Table 3. Protection efficiency in mice immunized with fimbrial proteins of different B. bronchiseptica strains after intraperitoneal challenge with live $B$. bronchiseptica F415.

Tablo 3. Değişik $B$. bronchiseptica suşlarına ait fimbriya proteinleri ile bağışıklanmış farelerde periton-içi canlı B. bronchiseptica F415 uygulamasına karşı korunma.

\begin{tabular}{ccccc}
\hline $\begin{array}{c}\text { Fimbrial proteins } \\
\text { used in } \\
\text { immunization }\end{array}$ & $\begin{array}{c}\text { Mice } \\
\text { (immunized with } 2 \times 12.5 \mu \mathrm{g} \text { fimbriae) } \\
\text { alive/total }\end{array}$ & $\begin{array}{c}\text { Mrotection } \\
\%\end{array}$ & $\begin{array}{c}\text { Mice } \\
\text { (immunized with 2x25 } \mu \mathrm{g} \text { fimbriae) } \\
\text { alive/total }\end{array}$ & $\begin{array}{c}\text { Protection } \\
\%\end{array}$ \\
\hline F415 & $6 / 6$ & 100 & $6 / 6$ & 100 \\
3036 & $0 / 6$ & 0 & $6 / 6$ & 100 \\
UK6 & $0 / 6$ & 0 & $5 / 6$ & 84 \\
UK7 & $0 / 6$ & 0 & $3 / 6$ & 50 \\
4617 & $0 / 6$ & 0 & $0 / 6$ & 0 \\
CA & $0 / 6$ & 0 & $0 / 6$ & 0 \\
219 & $0 / 6$ & 0 & $0 / 6$ & 0 \\
\hline
\end{tabular}

Besides, low antibody levels with serum dilutions of $1: 100$ or 1:200 were observed for sera of mice immunized with whole cell $B$. bronchiseptica standard strains and isolates in ELISA based on F415-fimbriae, with the exception of strain 3036, giving positive reaction at serum dilution of 1:1600 (Data not shown).

Protection against letal challenge: Mice immunized with $12.5 \mu \mathrm{g}$ of the fimbrial proteins were not protected against intraperitoneal challenge of $4 \mathrm{LD}_{50}$ of strain F415, except the mice immunized with the challenge strain (Table 3), however, protection was obtained with $25 \mu \mathrm{g}$ of the fimbrial proteins belonging to some of the strains. Immunization with the fimbrial proteins of F415 and 3036 protected $100 \%$ of the mice, UK6 and UK7 protected $84 \%$ and $50 \%$ of the mice respectively. No protection was observed with 4617 , CA and 219 strains.

\section{Discussion and Conclusion}

In the present study, the immunogenicity and protective immune response of the fimbrial proteins obtained from 7 B. bronchiseptica strains were discussed. For this purpose, fimbrial proteins were partially purified after urea-heat extraction of the bacteria as described by Irons et al. (1985). The extracts of B. bronchiseptica strains were determined to possess the major antigens; FHA (220 kDa), AC-Hly (200 kDa), $40 \mathrm{kDa}$ protein, 35 $\mathrm{kDa}$ protein and fimbrial subunits which have important roles in pathogenicity by SDS-PAGE and western-blot analysis (Fig 1). The synthesis of FHA and AC-Hly was also demonstrated previously by determination of hemagglutination and hemolytic activities of these antigens (5). The presence of fimbrial subunit proteins altered depending on the strains as one or two bands at 21 and $22 \mathrm{kDa}$.

The immuno-reactivity of the fimbrial proteins was also determined by dot-blot analysis with anti- $B$. bronchiseptica mouse sera. Besides, determination of the positive reaction although not strong with $B$. pertussis
anti-Fim2,3 polyclonal sera was important for confirmation of the fimbrial subunits. The identity between the nucleotide sequences of the fim 2 and fim 3 genes belonging to $B$. bronchiseptica and $B$. pertussis encoding the major fimbrial subunits was determined as $74 \%$ and $94 \%$, respectively (27) and B. bronchiseptica fimbrial subunits were characterized with western blot analysis by using antisera raised against $B$. pertussis serotype 2 and 3 fimbriae $(21,27)$. Detection of specific antibody response for $35 \mathrm{kDa}$ and $40 \mathrm{kDa}$ proteins by western blot analysis of the strains showed the importance of these proteins in whole-cell immunization. The $35 \mathrm{kDa}$ protein is probably an outer membrane porin protein (24) also shown to be recognized by B. pertussis serotype 2 sera (21). The $40 \mathrm{kDa}$ protein is supposed to be FimD, minor subunit of fimbriae $(8,31)$.

For determination of the immunogenicity of the fimbrial proteins, mice were immunized with 12.5 $\mu \mathrm{g} /$ dose and $25 \mu \mathrm{g} /$ dose of the proteins. (Table 1 ). In this frame, the microagglutination titers of anti-fimbriae sera belonging to the strains F415, 3036, and the isolates UK6 and UK7 were moderately high against the challenge strain F415 in comparison with the strains 4617 and 219 as well as the isolate CA. The immunoreactivity of antifimbriae sera of strains F415, UK7, CA, 4617 with $B$. pertussis Saadet strain (serotypes 2 and 3) in microagglutination test, but no reaction with Tohama strain (serotype 2) showed that these B. brochiseptica strains cross-reacted with serotype 3 of $B$. pertussis. The reactivity of anti-fimbriae 3036 and UK6 sera with both Saadet and Tohama strains showed the cross-reactivity with both serotypes 2 and 3. Anti-fimbriae 219 sera reacted only slightly with Tohama strain (Table 1).

Considering the data from our previous study, the microagglutination titres of anti-fimbriae sera are lower than that of anti-whole cell sera of the same strains against strain F415 (1:512 to 1: 2048), except two strains 4617 and 219 (5). The high level of antibody response 
was probably due to the other agglutinogen proteins, FHA and pertactin in addition to the partially purified fimbriae. These results were compatible with the high level protection (80-100) of mice immunized with whole cell strains against challenge with strain F415 (5).

High IgG antibody titers of anti-fimbriae belonging to strains F415 and 3036 and the isolates UK6 and UK7 were obtained in ELISA (Table 2) in accordance with the results of Burns et al. (1993) also compatible with the results of microagglutination test. The antibody titers were decreased for CA, 4617 and 219. For most of the strains, the antibody response against the fimbrial antigens seemed to be weaker than the response against the rest of the immunologically important antigens occurring after whole-cell immunization, proposing the importance of strain difference and the efficiency of the other immuno-dominant antigens in immune response $(6$, 10, 15).

Four out of 7 groups of mice immunized with the fimbriae of different strains were protected at 50-100\% against $4 \mathrm{LD}_{50}$ intraperitoneal challenge with strain $\mathrm{F} 415$. Immunization with fimbriae of F415 and 3036 protected $100 \%$ of the mice consistent with the results obtained with F415 fimbriae based-microagglutination and ELISA. Although this was expected for the challenge strain F415, the high protective efficiency of F415 fimbriae against many virulence associated antigens is still important. The microagglutination and ELISA results were also considerable for the isolates UK6 and UK7 with the protection efficiencies of 84 and 50\% respectively. Mice immunized with the strains 4617, 219 and CA were not protected and the serological test results were moderately lower than the other strains.

In conclusion, the level of antibody response to fimbriae of various $B$. bronchiseptica strains was found in some extent protective against experimental infection in mice. As the protection efficiency of the fimbriae of different strains varies from one to another, the fimbriae belonging to F415, 3036 and UK6 strains would be used as one of the protective antigens for developing an efficient $B$. bronchiseptica subunit vaccine. In addition, F415, 3036 and UK6 fimbriae have the potential to be used as diagnostic antigens for evaluation of the infection status and monitoring of vaccine efficacy. Further investigations will be necessary to evaluate the potential use of the fimbriae in vaccine and diagnostic purposes in the natural host.

\section{Acknowledgements}

The authors thank Prof. Dr. Jale ERDEĞER and Dr. Lale ATASEVEN for kindly providing some of the $B$. bronchiseptica isolates.

\section{References}

1. Bemis DA, Greisen HA, Appel MJG (1977): Pathogenesis of canine Bordetellosis. J Infect Dis, 135, 753-762.

2. Binns SH, Dawson AJ, Speakman AJ, Cuevas LE, Gaskell CJ, Hart CA, Morgan KL, Gaskell RM (1999): Prevalence and risk factors for feline Bordetella bronchiseptica infection. Vet Rec, 144, 575-580.

3. Boschwitz JS, van der Heide HGJ, Mooi FR, Relman DA (1997): Bordetella bronchiseptica expresses the fimbrial structural subunit gene fimA. J Bacteriol, 179, 7882-7885.

4. Burns EH, Norman JM, Hatcher MD, Bemis DA (1993): Fimbriae and determination of host species specificity of Bordetella bronchiseptica. J Clin Microbiol, 31, 1838-1844.

5. Büyüktanır Ö, Akan M, Özcengiz E (2005): Değişik Bordetella bronchiseptica suşlarında virulans faktörleri ve immünojenik özellikler. Türk Mikrobiol Cem Derg, 35, 248-255.

6. Cotter PA, Yuk MH, Mattoo S, Akerley BJ, Boschwitz J, Relman DA, Miller JF (1998): Filamentous hemaglutinin of Bordetella bronchiseptica is required for efficient establishment of tracheal colonization. Infect Immun, 66, 5921-5929.

7. Dworkin MS, Sullivan PS, Buskin SE, Harrington RD, Olliffe J, Mac Arthur RD, Lopez CE (1999): Bordetella bronchiseptica infection in Human Immunodeficiency Virus-infected patients. Clin Infect Dis, 28, 1095-1099.

8. Geuijen CA, Willems RJL, Bongaerts M, Top J, Gielen H, Mooi FR (1997): Role of the Bordetella pertussis minor fimbrial subunit, FimD, in colonization of the mouse respiratory tract. Infect Immun 65, 4222-4228.

9. Goodnow RA (1980): Biology of Bordetella bronchiseptica. Microbiol Rev, 44, 722-738.

10. Gueirard P, Guiso N. (1993): Virulence of Bordetella bronchiseptica: Role of adenylate cyclase-hemolysin. Infect Immun 61, 4072-4078.

11. Holt JG, Krieg NR, Sneath PHA, Staley JT, Williams ST (1996): Bergey's Manual of Determinative Bacteriology. Williams and Wilkins, Ninth Edition.

12. Irons LI, Ashworth LAE, Robinson A (1985): Release and purification of fimbriae from Bordetella pertussis. Develop Biol Standard 61, 153-163.

13. Jacobs AAC, Chalmers WSK, Pasman J, van Vugt F, Cuenen LH. (1993): Feline bordetellosis: challenge and vaccine studies. Vet Rec, 133, 260-263.

14. Kania SA, Rajeev S, Burns Jr EH, Odom TF, Holloway SM, Bemis DA (2000): Characterization of fimN, a new Bordetella bronchiseptica major fimbrial subunit gene. Gene, 256, 149-155.

15. Kobisch M, Novotny N (1990): Identification of a 68kilodalton outer membrane protein as the major protective antigen of Bordetella bronchiseptica by using specificpathogen-free piglets. Infect Immun, 58, 352-357.

16. Kume K, Nakai T, Samejima Y, Sugimoto C (1986): Properties of dermonecrotic toxin prepared from sonic extracts of Bordetella bronchiseptica. Infect Immun, 52, 370-377. 
17. Laemmli UK (1970): Cleavage of structural proteins during the assembly of the head of bacteriophage T4. Nature (London), 227, 680-685.

18. Lee SW, Way AW, Osen EG (1986): Purification and subunit heterogeneity of pili of Bordetella bronchiseptica. Infect Immun, 51, 586-593.

19. Mattoo S, Miller JF, Cotter PA (2000): Role of Bordetella bronchiseptica fimbriae in tracheal colonization and development of a humoral immune response. Infect Immun, 68, 2024-2033.

20. Mattoo S, Cherry JD (2005): Molecular pathogenesis, epidemiology and clinical manifestations of respiratory infections due to Bordetella pertussis and other Bordetella subspecies. Clin Microbiol Rev, 18, 326-382.

21. Mooi FR, van der Heide HGJ, ter Avest AR, Welinder KG, Livey I, van der Zeijst BAM, Gaastra W (1987): Characterization of fimbrial subunits from Bordetella species. Microb Pathog, 2, 473-484.

22. Novotny P, Kobisch M, Cownley K, Chubb AP, Montaraz JA (1985): Evaluation of Bordetella bronchiseptica vaccines in specific-pathogen-free piglets with bacterial cell surface antigens in Enzyme-Linked Immunosorbent Assay. Infect Immun, 50, 190-198.

23. Parker CD, Payne BJ (1985): Manual of clinical microbiology. Fourth edition. ASM Chapter 34, 394-399.

24. Passerini De Rossi BN, Friedman LE, Gonzalez Flecha FL, Castello Franco MA, Rossi JP (1999): Identification of Bordetella pertussis virulence-associated outer membrane proteins. FEMS Microbiol Lett, 172, 9-13.

25. Powell HM (1951): Charcoal agar culture medium for preparing H. pertussis vaccine. Bul Hlth Rep, 66, 346-348.

26. Riboli B, Pedroni P, Cuzzoni A, Grandi G, de Ferra F (1991): Expression of Bordetella pertussis fimbrial (fim) genes in Bordetella bronchiseptica: fimX is expressed at a low level and vir-regulated. Microb Pathog, 10, 393-403.
27. Savelkoul PH, de Kerf DPG, Willems RJ, Mooi FR, van der Zeijst BAM, Gaastra W (1996): Characterization of the fim 2 and fim 3 fimbrial subunit genes of Bordetella bronchiseptica: Role of Fim 2 and Fim 3 fimbriae and flagella in adhesion. Infect Immun, 64, 5098-5105.

28. Shina A, Hart CA, Stenton MD, Dawson S, McCracken CM, Binns S.H, Gaskell RM, Winstanley C (2002): Distribution of fim 3 and flaA TTGE sequence types amongst isolates of Bordetella bronchiseptica from different host animals. J Med Microbiol, 51, 557-563.

29. Towbin H, Staehelin T, Gordon J (1979): Electrophoretic transfer of proteins from polyacrylamide gels to nitrocellulose sheets: procedure and some applications. Pro Natl Acad Sci USA, 76, 4350-4354.

30. World Health Organization (WHO) Manual (1977): Manual for the production and control of vaccines, pertussis vaccine. BLG/UNDP/77.3 Rev. 1

31. Willems RJL, Geuijen C, van der Heide HGJ, Matheson M, Robinson A, Vesiuis LF, Ebberink R, Theelen J, Mooi FR (1993): Isolation of a putative fimbrial adhesin from Bordetella pertussis and the identification of its gene. Mol Microbiol, 9, 623-634.

Geliş tarihi: 27.10.2010 / Kabul tarihi: 12.07.2011

Address for Correspondence:

Dr. Erkan Özcengiz

Vaccine Biologicals Research Inc.

Hacettepe University

Teknokent 1.Ar-Ge No: 4 Beytepe, Ankara/Turkey.

E-mail: erozcengiz@vbrasi.com.tr 